DOI https://doi.org/10.30525/978-9934-26-110-7-51

\title{
COMMUNICATIVE RELEVANCY, FUNCTIONAL AND SEMANTIC POTENTIAL OF ENGLISH COMPOSITE IDIOMS IN SOCIOCULTURAL ASPECT
}

\author{
Onyshchenko I. A. \\ Senior Lecturer at the Foreign Languages Department \\ for Natural Sciences and Mathematics \\ Lesya Ukrainka Volyn National University \\ Kyrykylytsia V. V. \\ PhD in Pedagogical Sciences, Associate Professor, \\ Associate Professor at the Foreign Languages Department \\ for Natural Sciences and Mathematics \\ Lesya Ukrainka Volyn National University \\ Trotsiuk A. M. \\ PhD in Philological Sciences, Associate Professor. \\ Head of the Foreign Languages Department \\ for Natural Sciences and Mathematics \\ Lesya Ukrainka Volyn National University \\ Lutsk, Ukraine
}

It need hardly be emphasized that the connection between language and culture is great, the latter being language's instrument and incarnation. Culture is a peculiar historical memory of the people. Both language and culture exist in a close dialogue with each other. The necessity to apply linguistic knowledge in the dialogue of cultures actualizes the problem of socio-cultural and socio-linguistic competencies formation [4, p. 237-238] which is the basis of the theory of intercultural communication. Knowledge of the social and cultural life of the people who speak the language is an integral part of its use in real communication [3, p. 42].

It is seen at once that phraseology of every language appears to be a linguistic heritage of utmost significance that reveals the conception of the world, national culture, customs, traditions, beliefs, imagination, lifestyles, and history of the people speaking a definite language. It is the idiomatic phraseology that makes it possible to penetrate into the remotest past of the language, as well as the history and culture of its native speakers. [8, p. 58]. 
Here are some examples to illustrate what has been said: 1. A humorous term of great interest is wrap-rascal. It is defined as a loose greatcoat worn by people of elegance about 1740, in supposed imitation of the coarse coats of poorer people; hence, any long outer garment. The driver, by means of a wraprascal, had covered a great part of the rags of his lower garments 2 . Black bottom, a dance popular in the mid to late 1920s that involved a sinuous gyrating of the hips (originally, US). The name probably reflects the hip movements, but it may also have been subconsciously prompted by the already existed black bottom «low lying area inhabited by black». Also recorded as a verb, New York Times: It occurred to the producer that if you could dance before the beat you would have a new rhythm... The result is the Black Bottom. 1927 Daily Express: Miss Bradhurst had black bottomed nineteen miles ... before she collapsed [1, p. 128].

It is also worth mentioning that English composite idioms representing particular semantic condensates of their correlative phraseological units contribute a lot to idiomatic heart of the English language, the meaning of their components being out of connection from their dictionary meaning: brownnose - a toady, wheedle, sycophant; wind-bag - a chatterbox, (idle) talker; wool-gathering - daydreaming.

It is evident from numerous examples that most composite idioms are characterized by bright expressive negative, in some cases even brutal attitude towards the referent; $a$ wet blanket - a bore; leg-pulling - 1. toad-eating, 2. blackmail; pea souper - a dense yellow fog; pot-boiler - 1. slapdash work, 2. botcher; free-booter - a pirate; wall-flower - a girl who was not proposed to dance; muck-racker - a person who investigates carefully unmasking (in press) dark plots of political and governmental figures.

Colloquialisms, jargon, slang, dialects are powerful enough to mark the language giving signals about social, cultural, communicative status of the speaker. The speaker's status can be defined by his social position, world outlook, and cultural level, intellectual and moral development [6, p.165].

Brightly expressed negative emotional tone that is typical of a great number of composite idioms complicates denotative sense of the direct nominative meaning. They are coined in the process of linguo-creative mental activities and rest on the background knowledge of the individual who gets information from his personal world: baby-kisser - a candidate who stands for an election; doorbell-ringing - making rounds of the flats and houses by the agitators (before an election); bell-ringer - a local political public figure; redneck, (American) - a white farm-hand.

Phraseological composition is an important source of linguistic enrichment at the expense of means of its own. It becomes possible due to the unique 
ability that lies in the very system of the language to create new signs on the basis of the existing ones. The domain of idioms is closely connected with everyday life, religious sermons, material and spiritual national culture, rules of common life and customs of the linguistic social community [8, p. 63-64]: bad hair day - a day on which one's hair is particularly unmanageable; hence, a day, on which everything seems to go wrong: «Soon you will notice how much less complaining you do even on bad hair days» [1, p. 135]; jelly-babya soft gelatous sweet in the shape of a baby; Bible Belt - the South and the Middle West of the USA where Protestant fundamentalism is a powerful force: "I'm collecting parsons, Gilbert, ... That's why I've been living in Kansas City. It's the centre of the Bible Belt [1, p. 127].

The importance of such «encyclopedic composites» can be revealed only due to definite background sociolinguistic knowledge of history, literature, customs, traditions, beliefs, lifestyles of some national mentality [5, p. 11]: glass ceiling - an unofficial or unacknowledged barrier to personal advancement, especially of a woman or member of an ethnic minority in employment: "I call it the glass ceiling. They are in the top of middle management and they are stopping and getting stuck [1, p. 542].

The fact is, however, that the reader's incomplete information awareness of history, culture, realia, myths, legends, customs, traditions of another ethnic group causes communication noise that reduces the effectiveness of communication and may result in complete discontinuance to it [7, p. 51]: baglady - a homeless woman, often elderly, who carries her possessions in shopping bags: "Letty, the Bag Lady ... would pack all her valuables in two large shopping bags and carry them with her.»; "They even had a couple of back-clad bagladies sitting silently on straight chairs by the door» [1, p. 460].

Modern English colloquialisms, slang, jargon represent a steady lexicogrammatical «reserve» that supplies literary language with linguistic resources which form speech. It should be noted that American English is particularly rich in jargon and slang. Probably, the social conditions that made American nation resulted in the appearance of the stylistically marked colloquial models of word building. One of the most important reasons of their appearance lies in ethnic dissimilarity, mostly typical of social lower classes as well as of the external democracy of social higher-ups, which admit wide usage of bright, «rich» colloquialisms in their official speeches, radio, television, including advertisement.

England with its traditional restraint of linguistic activities is more conservative in this respect forbidding the formation of expressive reduced word building models in its linguistic system. Nevertheless, stylistically marked models of the derivatives are formed according to general laws that 
demonstrate their Germanic origin: beetle-crusher - an infantry man, a cop; brown-bagger - a crammer: freeloader - a sponger who is eager to eat and drink at somebody's expense; woolly-head - a negro; blue-stocking - an educated woman, a pedant; brown-nose - a toady, sycophant; panhandler a beggar; frog-eater - a Frenchman; meat-eater - an Englishman [2, p. 102-103].

To summarize the data that have been analyzed so far, it can be said that English composite idioms represent rather specific semantic condensates of their correlative phraseological units. It is obvious that they have enriched the idiomatic heart of the English language. Numerous examples prove that composite idioms are characterized by vivid expressive negative attitude towards the referent. They reveal the speaker's status that can be defined by his social position, world outlook, and cultural level, intellectual and moral development. The domain of composite idioms is in close contact with everyday life, religious sermons, material and spiritual national culture, rules of common life conditions, customs and traditions of a definite linguistic social community. The meaning of the composite idioms is comprehensible only due to corresponding background sociolinguistic knowledge of history, literature, customs, traditions, imaginations of a certain national mentality. These are colloquialisms, jargon, and slang that present a steady «reserve» which supplies literary language with bright and rich linguistic means that are forming speech.

\section{References:}

1. Ayto J. Twentieth Century Words. Oxford University Press, 1999. $626 \mathrm{p}$.

2. Бєляєва Т. М., Хомяков В. А. Нестандартная лексика английского языка. Ленинград: Изд-во ЛГУ, 1985. 136 с.

3. Куликова Л., Тарасенко Т. Діалог культур у теорії міжкультурної комунікації та практиці викладання іноземних мов. Науковий вісник Мелітопольського держ. пед. ун-ту. Серія: Педагогіка. 2017. № 1 (18). С. 42-46.

4. Методика навчання іноземних мов у загальноосвітніх навчальних закладах : підруч. / Л. С. Панова та ін. Київ. : ВЦ «Академія», 2010. 328 с.

5. Мешков О. Д. Семантические аспекты словосложения английского языка. Москва: Наука, 1986. 208 с.

6. Полюжин М. М. Диахронно-семантический аспект префиксального словообразования в английском языке: автореф. дис. ... докт. фил. наук : 10.02.04. Москва, 1992. 45 с. 
7. Селиванова Е. А. Лингвокультурный аспект коммуникативного шума. Науковий вісник кафедри ЮНЕСКО Київськ. держ. лінгв. ун-ту. Серія: Філологія. Педагогіка. Психологія. 2000. № 3А. С. 51-52.

8. Черданцева Т. И. Идиоматика и культура. Вопросы языкознания. 1996. № 1. С. 65-69.

DOI https://doi.org/10.30525/978-9934-26-110-7-52

\title{
СИМВОЛІЧНІ ОБ'СКТИ ЕТНОФРАЗЕОЛОГІЗМІВ
}

\author{
Онуфрійчук Г. I. \\ кандидат філологічних наук, \\ доцент кафедри украӥнської мови та культури \\ Наиіональний авіаційний університет \\ м. Київ, Украӥна
}

Однією 3 найважливіших ознак мовленнєвої діяльності людини $є$ символ, що базується на основі метафоричності. Адже буття кожного повсякчас перебуває у колі певних символів, що пов'язано з розумінням природи мови. Природа символу в будь-якому аспекті здавна хвилює вчених різних галузей. До неї одночасно зверталися філософи, психологи, культурологи, фольклористи, лінгвісти та ін. Значна частина науковців стверджує, що символізм постав із занепадом первісних релігій. Зрештою, кожен жест, звук, слово були в певному розумінні символами й нерідко залишаються такими й досі.

Взаємодія фізичного й метафоричного в свідомості людини спонукає мислити образами. Предметний світ, входячи до сфери духовного, зазнає в людській свідомості «символізації, бо символ - це «річ», розглянута як одиничність і співвіднесена 3 довкільною ії інакшістю». Основа символізму - закон аналогії, бо все в предметному світі взаємопов'язане i становить універсальну систему як фундаментальну єдність. Символічний порядок речей як корекція у плані значення між матеріальним i духовним світом, між світом видимим i невидимим, передбачає символізовані форми вираження [3, с. 58-59].

Сучасне уявлення про символи, що грунтується на семіологічній концепції, полягає в прирівнюванні їх до знаків, де відношення між позначуваним і позначеним умовне. У більш радикальному тлумаченні символ відповідає тільки одному позначуваному і тим самим відрізняється від двостороннього знака-символа. У результаті виникло 